\title{
The Belhar Confession in its historical context
}

NGTT DEEL 55, NO 1, 2014

\section{Plaatjies-van Huffel, Mary-Anne}

Stellenbosch University

\begin{abstract}
In this article I work with the presupposition that the time has arrived that the Belhar Confession should be detached from being a document utilized for advocacy perusal only. The Belhar Confession should rather be interrogated as a historical document in the true sense of the word. This will be helpful in construing the Belhar Confession as a discursive instrument in the discourse on social justice issues both local and global. The article is divided into four parts. In the first part the focus is largely on the socio political context of SA during 1960-1990. In the second part the influence of the ecumenical movement on the discourse on social justice is being attended to. Thirdly I attend to the drafting of the Belhar Confession and lastly attention will be given to the reception of the Belhar Confession (1982-1990).
\end{abstract}




\section{ANALYSING THE BELHAR CONFESSION AS A HISTORICAL DOCUMENT}

A few months ago I held in my hand for the first time the original texts of the Belhar Confession, handwritten in green and red ink by Prof. Dirkie Smit, one of the co-drafters of the Belhar Confession. Until recently, the original documents were never disclosed. Smit kept the original draft of the Belhar Confession in a drawer in his study for more than thirty years. Suddenly I had to ask myself the very same questions which researchers ask themselves concerning historical texts. What is the context? What is the setting? (Sitz im Leben?). Where, why and when was it written? Who is the author and what is her or his place, position, role, reputation, status in society? What kind of document is it? What point is the author trying to make? What was the motive (purpose) of the author(s) in preparing it? Who was it written for? What is known about the audience? What is the argument and strategy utilised by the authors to achieve their goals? During the past three decades, the interpretation of the Belhar Confession had been for the most part ideologically loaded due to the fact that it was mainly used for advocacy perusal. ${ }^{1}$ The file, which Dirkie Smit handed to me, consists of the early handwritten notes, the first draft, the first English and German translations of the Belhar Confession as well as the accompanying letter. Much had changed in the final draft before it was tabled at the synod. The insertions, changes, deletions and even omissions by the commission can easily be seen in the original handwritten documents. The handwritten text was typed by Ms. Pontac, the administrative clerk in Prof. Jaap Durand's office at University of the Western Cape (UWC).

1 Van Houten, R. L. 1997. Introduction. Theological Forum 25, (No. 4, December 1997); CRCNA Acts 1990 Online at http://www.crcna.org/pages/belhar.cfm [Accessed 22 March 2011]; Adler, E. 1974. A small beginning. An assessment of the first five years of the Programme to Combat Racism. Geneva: WCC; Botha, J. 1991. Belhar: Yes or no? Theological Forum 19, (No. 2, July), 2-10; Cloete, G. D. \& Smit, D. J. 1984. A Moment of Truth: The Confession of the Dutch Reformed Mission Church. Grand Rapids: Eerdmans; Klooster, F. 1991. The Belhar Confession 1986. Theological Forum 19, (No.1, March), 14-17; McGarrahan, E. T. 2010. A Study of the Belhar Confession and its Accompanying Letter. Office of Theology and Worship, General Assembly Council Presbyterian Church (USA). Online at https://www.pc-biz.org/Explorer. aspx?id=3353\&promolD=17 [Accessed 22 March 2011]; Meiring, P. 1991. The Belhar Confession 1986: A Dutch Reformed perspective. Theological Forum 19, (No. 1, March 1991), 18-23. 


\section{WHEN IN TIME WAS THE BELHAR CONFESSION WRITTEN?}

One of the first questions one has to address, amongst others, is about the timeframe, namely: When was this document produced? Is it contemporary to the events/issues it describes? In what context was it produced? The place in time must be identified in order to understand whether the Belhar Confession has a certain effect on the status quo. The Belhar Confession, drafted in 1982 by the DRMC, has its roots in the struggle against apartheid in Southern Africa.

The international ecumenical movement played a critical role in the anti-apartheid struggle and the ultimate decision of the DRMC during their synod in September 1986. During the 1980s, the DRMC became a member of the Reformed Ecumenical Council (REC), the World Council of Churches Programme (WCC), the World Alliance of Reformed Churches (WARC) as well as the South African Council of Churches (SACC). Dirkie Smit represented the DRMC on the commission for human rights of the SACC. ${ }^{2}$ The ecumenical movement influenced the discourse on race relations in the black Reformed churches in South Africa and ultimately the formation of the Belhar Confession. For example, the WCC's Programme to Combat Racism was extensively discussed at the DRMC synod in 1982, and it had a bearing on decisions made regarding racism and apartheid at the same synod. The DRMC sent a full delegation, spearheaded by Dr. Allan Boesak, to the WARC general assembly which met in August 1982 in Ottawa, Canada. In his paper "He made us all, but..." prepared for the assembly, Allan Boesak pointed out that the WARC had a responsibility towards its member churches in South Africa who suffered under the apartheid theology and policy ${ }^{3}$. Furthermore, Boesak introduced a motion at the assembly requesting that the WARC declare apartheid a heresy. Subsequently the WARC general assembly declared that the situation in South Africa constituted a status confessionis. According to Smit, one of the co-drafters of the Belhar Confession, the expression status confessionis means "that a Christian, a group of Christians, a church, or a group of churches are of the opinion that a situation has developed, a moment of truth has dawned, in which nothing less than the gospel itself, their most fundamental confession concerning the Christian gospel, is at stake, so that they feel compelled to witness and act over against this threat." 4 Apartheid constituted a status confessionis in which the truth of the Gospel and the Reformed faith was at stake. Status confessionis therefore means that it was impossible to disagree on the issue of apartheid without the integrity of the common confession

2 Agenda en Handelinge NGSK 1982 (Agenda and Proceedings DRMC 1982), 21.

3 Boesak, A. A. 1984. Black and Reformed. Bellville: Skotaville Publisers, 117.

4 Cloete \& Smit, A moment of truth, 16. 
as Reformed church being seriously endangered. The WARC declared with black Reformed Christians of South Africa that apartheid (separate development) is a sin, and that the moral and theological justification of it is a travesty of the Gospel and, in its persistent disobedience to the Word of God, a theological heresy. ${ }^{5}$ The WARC consequently suspended the membership of the DRC as well as that of the Nederduitsche Hervormde Kerk (NHK) in South Africa.

At the DRMC Synod of 1982, the members of the Confessing Circle played a pivotal role in the deliberations. The Confessing Circle, originally called the Broederkring (Circle of Brothers) (BK), was constituted by black and white clergy, evangelists, church council members and lay members of the DRMC and the DRCA. It had set itself the goal of guiding and pressuring the church in the struggle against apartheid and attaining church unity, especially affecting debates on synodical level with regard to social justice issues. Because of its opposition to apartheid, the members of the BK became victims of security legislation. The BK was viewed as the authentic voice of the oppressed within the DRCA and DRMC. The BK period represents the struggle within the church. The BK swayed the theological thinking of the DRMC and the DRCA, and ultimately influenced the drafting and acceptance of the Belhar Confession. ${ }^{6}$

\section{GEOGRAPHICAL AND HISTORICAL LOCATION OF THE BELHAR CONFESSION}

Questions such as the following should be asked: Where, why and when was the Belhar Confession written? Where was this document produced? Does the geographical location influence the content? Where is the targeted audience located, and what is their situation? If the situation and location of the audience is misunderstood, the principles in the Belhar Confession, namely unity, reconciliation, and justice, can easily be misapplied. The Belhar Confession, like all other classical confessions, originated in a specific historical context. The Heidelberg Catechism, Belgic Confession, the Canons of Dort, Barmen Declaration, et cetera, were undisputedly occasioned by the religious and political discourse in their countries of origin. In this regard, the Belhar Confession is no exception. The socio-political realities in apartheid South Africa had a bearing on the decisions of the DRMC synod of 1982,

5 WARC Seoul 1990. 1989 Proceedings of the 22nd General Council, ed. Edmond Perret, Geneva: WARC, 173-175, 279-281; Ottawa 1982. Proceedings of the $21^{\text {st }}$ General Council of the World Alliance of Reformed Churches, 177f., Ottawa, Canada, August 17-27, 1982. Geneva, Offices of the WARC, 1983.

6 Submission of the URCSA to the TRC 1997. URCSA: Bloemfontein, 1-5. 
which convened in Belhar. The Belhar Confession is in the first instance restricted to the issues facing the Reformed churches in South Africa during apartheid. The name Belhar in the Confession refers to a township in Cape Town, constituted by the apartheid government for the so-called coloured people in which to reside. The apartheid government had set up semi-urban townships for black, Indian and coloured population groups, of which Belhar is merely one. The adoption of the Belhar Confession, therefore, did not take place in a political vacuum. It was adopted in a so-called coloured township, in a Reformed church especially constituted for people of mixed descent. The delegates at the DRMC synod of 1982 in Belhar were members of a racially segregated church which had been constituted by the Dutch Reformed Church in South Africa (DRC).

According to Coertzen (2010:51) there is a duality in the mission strategy of the DRC. On the one hand new converts from the so called heathendom became members of the existing congregations of the DRC, whilst on the other hand provisions had been made on a growing account for separate ministry to the "Coloured" church members. Until the end of the eighteenth century, converts from indigenous people, slaves and members of the DRC jointly attended services and received their sacraments together. ${ }^{7}$ After 1828, there were several problems in Stellenbosch, Calvinia, Caledon, Riversdale and the Swartland, relating to the admission of black Christians to the Lord's Table. ${ }^{8}$ On 29 April 1829, the presbytery of Cape Town of the Dutch Reformed Church in South Africa (DRC) dealt with an enquiry of the Swartland congregation with regard to the administering of Holy Communion to people of mixed descent. At the 1829 synod of the Dutch Reformed Church in South Africa, the issue with regard to administering Holy Communion to people of mixed descent came under discussion. The church council of Swartland submitted a motion relating to administering Holy Communion to people of mixed descent: "Of personen van de kleur, die door het doen van de belydenis en de toediening van den H. Doop tot leden van de Kerke zijn aangenomen - gelijk

7 Kriel, C. J. 1963. Die geskiedenis van die Ned. Gereformeerde Sendingkerk in Suid-Afrika 1881-1956. 'n Historiese studie van die sendingwerk onder die Kleurlingbevolking van Kaapland (The history of the Dutch Reformed Mission Church in South Africa 18811956. A historical study of the mission work among the coloured people of the Cape Province). Paarl: Paarldrukpers, 54.

8 Loff, C. J. A. 1981. Dogter of verstoteling? Kantaantekeninge by die geskiedenis van die Ned. Geref. Sendingkerk in Suid-Afrika. (Daughter or ostracised? Side-notes to the history of the Dutch Reformed Mission Church in South Africa). Cape Town: Maranatha, 18-19. 
met geborene Kristenen het Avondmaal zal bediend worden." ${ }^{\prime 9}$ Rev. D. F. Berrangé and the commissioner of politics, Sir J. A. Truter, also took part in the discussion and inter alia stated that the discussion of the question was indeed unworthy of Christianity. ${ }^{10}$ At the synod, the separation at the communion table based on colour was unanimously rejected. The resolution reads as follows: "Te verklaren, dat men dit voorstel tot geen onderwerp van deliberatie of beslissing by de Synode behoorde te maken; maar hetzelve als een onwrikbaren stelregel op het onfeilbaar Woord van God gegrond, behoort te merken; dat bij gevolg, alle Christen gemeenten, en elk Christen in het bijzonder, verpligt is overeenkomstig te denken en te handelen."11 With this resolution, the synod of the Dutch Reformed Church in South Africa confirmed that all members, regardless of race, have access to the sacraments. The synods of the Dutch Reformed Church in South Africa of 1834, 1837 and 1857, again raised the issue of separate administration of the sacraments to the "gentiles." In the "Ontwerp van bepalingen Der Hervormde Zending Genootschappen in de Ned. Herv. Gemeenten in Zuid-Afrka van 1834", provisions had been made on the one side for the establishment of separate congregations for natives, but on the other side allowance was made for members of mixed descent to join existing DRC congregations. ${ }^{12}$ The above-mentioned provisions with regard to mission can be seen as the DRC's first mission policy. With the above-mentioned regulation, provision had been made for racially segregated congregations as well as the integration of races in one church. The first mission policy of the DRC was accepted in 1835 and was reviewed in $1837 .{ }^{13}$ In the regulation, provision was made for the establishment of free, but separated seats in the church for so-called heathen. Notwithstanding the decision of 1829, some congregations such as the Dutch Reformed Church in South Africa Ceres generated funds in order to construct buildings where the "heathen" could receive catechism and where the sacraments could be administered to them. For example, in Swellendam, there was a separate building for "heathen", which had

9 Acta van die Nederduitse Gereformeerde Kerk (Acts of the Dutch Reformed Church) 1829, 79, VI, 6. "Whether people of colour, who by being confirmed and having been baptised may be accepted as members of the church - together with born Christians will receive Holy Communion").

10 Kriel, Geskiedenis, 55.

11 Acta NGK 1829, 71-72. "To declare that one should not make this recommendation a topic of consideration or decision at the synod; but take into account this topic as an unyielding principle in the infallible Word of God; that consequently, all Christian congregations, and each Christian particularly, are obliged to reason and act accordingly."

12 Kriel, Geskiedenis, 49.

13 Adonis, J. A. 1982. Die afgebreekte skeidsmuur weer opgebou. Amsterdam: Rodopi, 78. 
already been completed during $1838 .{ }^{14}$ In 1855,45 white members applied to the church council of Stockenström that leave should be granted to them to celebrate the Holy Communion separately. The church council of Stockenström rejected the request and referred it to the presbytery of Albany. The latter unanimously decided to recommend to the church council of Stockenström that due to the biases and weaknesses of some of the congregants, the Holy Communion should be administered separately to "Coloureds" and Whites. ${ }^{15}$ According to Nicolaas Hofmeyer there should not be separation between so "Coloureds" and Whites, but, with regard to the efficiency of ministry, members from the "heathendom" should be minister separately from Whites, but they should remain members of the same congregation (Coertzen 2010:52). Hofmeyer saw the middle way approach as the most feasible: "De middenweg tusschen beide is de verkieslijke" (Coertzen 2010:52).

At the synod of the Dutch Reformed Church of South Africa in 1857, the issue of having separate Holy Communion services for different racial groups was again discussed. Rev. R. Shand of Tulbagh tabled an overture with regard to the abovementioned decision of the presbytery of Albany: "Of het de goedkeuring der Synode wegdraagt, dat in de Gemeenten der Nederduitsche-Gereformeerde Kerk, waar men het begeert, de gekleurden in een afzonderlijk gebouw, echter onder bestier en opzigt van den Kerkraad, alle voorregten der Christelijke Godsdiens afzonderlijk genieten zullen." ${ }^{16}$ His submission was keenly debated at the synod: The question which had to be considered was whether people of mixed descent who had been baptised and confirmed as fully-fledged congregants should be allowed to partake in the Lord's Supper together with white congregants, or whether the Holy Communion should be administered to them separately. On scriptural grounds, the synod could not approve this request. The synod of the Dutch Reformed Church of South Africa (1857), however, did approve it, due to the "weakness of some", to allow the creation of separate buildings for believers from heathendom.

De Synode beschouwt het wenschlijk en schrifmatig dat onze ledematen uit de Heidenen, in onze bestaande gemeenten opgenomen en ingelijfd worden, overal waar zulks geschieden kan; maar waar deze maatregel, ten gevolge van de zwakheid van sommigen de bevordering van de zaak van Christus onder de Heidenen, in de

14 Loff, Dogter of verstoteling, 22.

15 Kriel, Geskiedenis, 58.

16 Acta NGK 1857, 58, 60; Acta NGK 1857, 89, XII (5). "Whether the synod approves that in the congregations of the Dutch Reformed Church, where the desire exists, coloureds can enjoy all privileges of the Christian religion separately in a separate building, but under administration and supervision of the church council." 
weg zoude staan, de gemeenten uit de Heidenen opgerigt, of nog op te rigten, hare Christelijke voorregten in een afzonderlijk gebouw of gesticht genieten zal. ${ }^{17}$

According to Coertzen (2010:53) this decision, which put the context to allow separate ministries to people from different racial backgrounds, above Scripture, led ultimately to the constitution of separate churches in the Reformed Family. According to Chris Loff, the decision of the 1857 synod of the DRC opened the door for the establishment of racially segregated churches in 1881, namely the establishment of the Dutch Reformed Zendingkerk (Mission Church) of South Africa. ${ }^{18}$ With the above-mentioned decision, church apartheid was officially introduced into the Dutch Reformed Church. One should however, take cognisance of the fact that a large number of churches for people of mixed descent ("oefeninghuise" of "gestichte") already existed by 1857 . In Wagenmakersvallei and Tulbagh and many other places, the sacraments had been administered, long before the decision of 1857, separately to people of mixed descent. At the 1857 synod of the DRC, the church praxis merely became church policy. This decision led to the division of Christians on the basis of colour at the table of the Lord as a matter of practice and policy, and paved the way for the establishment of the first racially segregated Reformed church in South Africa, and ultimately societal apartheid. In October 1881, the DRC constituted the DRMC for people of mixed descent in Wellington. From 1910 until 1951, the DRC founded racially segregated churches in each province of South Africa, for African people in particular, which unified in 1963 in order to form the Dutch Reformed Church in Africa (DRCA). In 1968, the DRC founded a church for Indian people, namely the Reformed Church in Africa (RCA).

The DRC also played a pivotal role in the theological justification of what was later known as separate development. At a conference organised by the mission office of the DRC, which took place from 4-6 April 1950 in Bloemfontein, the "Naturellevraagstuk" (The Native Question) was discussed. "Die Naturellevraagstuk" ${ }^{19}$ tried to spell out exactly how different nations could live equally but separately in one geographical

17 The decision of the DRC synod reads as follows: "The Synod considers it desirable and according to the Holy Scripture that our heathen members (non-whites) be accepted and initiated into our congregations wherever it is possible; but where this measure, as result of the weakness of some, would stand in the way of promoting the work of Christ among the heathen people, then congregations set up among the heathen, or still to be set up, should enjoy their Christian privileges in a separate building or institution" (my translation), Acta NGK 1857, 60.

18 Loff, Dogter of verstoteling, 21.

19 Die Naturellevraagstuk: referate gelewer op die Kerklike Kongres van die Gefedereerde Ned. Geref. Kerke in Suid-Afrika, byeengeroep deur die Federale Sendingraad, Bloemfontein, 
area. The solution arrived at during that mission conference later became known as the policy of separate development. There was also an inexplicable absence of critique from both the DRMC and the DRCA on the Native Question. After its election victory, the National Party regime institutionalised and consolidated existing discriminatory and segregatory policies and bills. Numerous apartheid laws were passed from 1948 onwards, which confined the people of South Africa's life in minute detail. The government introduced these laws as an attempt to keep South African citizens apart on a racial and ethnic basis. ${ }^{20}$ For example, the apartheid laws laid down legal provisions on the specific areas where different population groups could own property, reside, work and even enjoy leisure. The Immorality Amendment Act, Act No. 21 of 1950, for example, prohibited adultery, attempted adultery or related "immoral" acts such as sexual intercourse between white and black people. The primary aim of the Group Areas Act, Act No. 41 of 1950 was to make residential separation compulsory. The Population Registration Act, Act No. 30 of 1950 provided that all South Africans should be racially classified in one of three categories: White, black or coloured. According to this Act, Indians fell in the coloured category. The racial classification of people was thereby entrenched. As a result of this Act, black people were forced to carry passbooks, the infamous "dompas" which had their fingerprints, photo and information, in order to access non-black areas. Although the members of the congregations of the DRMC and the DRCA directly suffered from the results of apartheid, for example, by forced removals, "dompas", migrant labour, group areas, racially segregated education systems, prohibition on mixed marriages, Bantustans, the decisions of the DRMC and DRCA synods from 1950-1974 reflect a perplexing apathy towards the sociopolitical situation in South Africa. In December 1960, shortly after the Sharpeville massacre, the WCC organised a consultation at Cottesloe Residence in Johannesburg for the South African churches to discuss the situation in South Africa. At that stage, the DRMC was not a member of the WCC and was therefore not obliged to prepare a response to the questions which the WCC had put to the member churches. Even after Cottesloe, both the DRMC and the DRCA did not straightforwardly reject the basic philosophy of segregation. They stated clearly in their submission to the Truth and Reconciliation Commission (TRC) their guilt of not voicing enough their objections against apartheid:

4-6 April 1950. Kerklike Kongres van die Gefedereerde Ned. Geref. Kerke in SuidAfrika: Bloemfontein.

20 Apartheid Legislation in South Africa. Online at http://www.sahistory.org.za/politics-andsociety/apartheid-legislation-1850s-1970s [Accessed 11 March 2011]. 
We confess our guilt that we have not always witnessed clearly enough in our situation and so are jointly responsible for the way in which those things which were experienced as sin, and confessed to be so, or should have been experienced as and confessed to be sin, have grown in time to seem self-evidently right and to be ideologies foreign to Scripture. ${ }^{21}$

For example, in 1971, the DRCA viewed the homeland policy as an acceptable alternative to the negative results of migrant labour. ${ }^{22} \mathrm{~A}$ lack of resistance during the above-mentioned period against the segregation policy at large was evident in both the DRMC and the DRCA.

Even Ras, Volk en Nasie en Volkereverhoudinge in die lig van die Skrif (RVN) (Human Relations and the South African scene in the light of the Scripture), published by the DRC as a comprehensive policy document during 1974, did not immediately raise any comments from the DRCA or the DRMC. The RVN supports the policy of separate development, of which the outline can be traced back to the 1950 Bloemfontein Conference. The white Afrikaans Reformed churches of South Africa throughout the years worked out in considerable detail the theological and moral justification for the system of apartheid. This situation brought a particular challenge to the church in South Africa. The mid-1970s, with the Soweto uprisings as a turning point, overturned just about everything within the DRMC and the DRCA. These churches did not remain untouched by the realities of the day. Hence, from 1974 onwards, both the DRMC and the DRCA put across their disapproval of the system of apartheid. During the 1970s, the communities served by the DRMC and the DRCA became increasingly involved in protesting against and opposing apartheid legislation in all spheres of life. Youth and student revolts resulted in expulsions and detentions, and ultimately some members of the DRMC and the DRCA even went into exile. ${ }^{23}$ As a consequence, during the 1980s, the DRMC and the DRCA strongly opposed the way in which the South African government used banning and detention without trial, and solitary confinement to silence those who criticised the unjust system of apartheid. For example Dr. A. A. Boesak, Reverends R. J. Stevens, A. Beukes, H. R. Botman, J. D. Buys, J. de Waal, E. Leeuw, B. Leuvenink, J. Thyse, A.

21 Submission of the URCSA to the TRC 1997, 5.

22 Acta van die Nederduitse Gereformeerde Kerk in Afrika 1971, 342. (Acts of the Dutch Reformed Church in Africa).

23 Submission of the URCSA to the TRC 1997, 5. 
J. Visagie, P. Moatse, K. E. Leputu, L. Mabusela, L. M. Matsaung, E. M. Tema, elder N. J. Matlakane, and others were convicted and imprisoned. ${ }^{24}$

During the 1978 and 1982 synods of the DRMC, numerous social justice issues were tabled and extensively deliberated upon. For example, the 1978 DRMC synod took cognisance of the RVN and stated that apartheid rested to a significant extent on the theological and moral justification of the system. The 1978 DRMC synod declared that apartheid and the moral and theological justification of it ridiculed the Gospel and was a theological heresy. ${ }^{25} \mathrm{~A}$ report on "Black power and black theology" was tabled on both the DRMC synods of 1978 and 1982. ${ }^{26}$ This report influenced the hermeneutics at work in the DRMC. At the 1982 DRMC synod, the role of the church and society in apartheid South Africa again came under scrutiny. A detailed report on apartheid, as well as ones on the ecumenical movement and the problem of racism (1924-1980), were tabled at the synod. ${ }^{27}$ Consequently, the DRMC called for the repeal of the Group Areas Act, Act No. 41 of 1950, which made the residential separation compulsory. At the same synod, the Immorality Amendment Act, Act No. 21 of 1950 and the Prohibition of Mixed Marriages Amendment Act No. 21 of 1968, which invalidated any marriage entered into outside of South Africa between a male citizen and a woman of another racial group, were critiqued for the very first time in the history of the DRMC. The synod urged the government to recall all laws against racially mixed marriages. ${ }^{28}$ The synod also affirmed that the migrant labour system was one of the factors which disrupted the stability of marriage and family life amongst black people. ${ }^{29}$

The 1982 DRMC synod noted the infringement of human dignity which the congregants had to endure due to the apartheid laws, namely separate entrances in business places, unequal salaries, inadequate housing, poor public services, racially divided beaches, poor sport facilities, job reservation to protect particular racial and ethnic groups, et cetera. ${ }^{30}$ The synod also noted the strong resentment amongst blacks against the racially segregated education system. The synod affirmed that

24 Agenda en Handelinge NGSK 1982, 25. (Agenda and proceedings of the Dutch Reformed Mission Church).

25 Agenda en Handelinge NGSK 1978, 2, 21.

26 Agenda en Handelinge NGSK 1978, 269-298; 1982, 377-380.

27 Agenda en Handelinge NGSK 1982, 32-34, 443-469.

28 Agenda en Handelinge NGSK 1982, 15.

29 Agenda en Handelinge NGSK 1982, 438.

30 Agenda en Handelinge NGSK 1982, 378-379, 431-443. 
equal educational facilities and opportunities should be provided for all. ${ }^{31}$ This set the scene for the decision of a status confessionis and the acceptance of the draft of the Belhar Confession at the same synod. In 1983, the DRCA declared migrant labour to be in conflict with the norms of Scripture and formulated a principled decision against it. ${ }^{32}$

\section{THE AUTHORSHIP OF THE BELHAR CONFESSION}

The next questions are: Who wrote the Belhar Confession? What is known about the author(s)? Who is/are the author(s) and what position, role, reputation, status, did the author(s) have at the time of writing? Was/were the author(s) well known at the time of writing? What was the purpose of the author(s) in preparing it? What biases or assumptions might have coloured the views of the author(s)?

The DRMC synod took place during September 1982, shortly after the WARC general council of 1982. The synod deliberated at length on the WARC's declaration of a status confessionis regarding apartheid. A lengthy report on apartheid was also tabled at the synod. Emotional contributions from clergy and church council members were uttered on the synod regarding the hardships people had to endure due to the policy and practice of apartheid. The synod declared a status confessionis regarding apartheid and reasserted that it was a heresy and a misrepresentation of the Gospel. The DRMC affirmed that apartheid contradicted the very nature of the church. Apartheid was seen as a structural and an institutional sin. The DRMC synod followed the WARC in rejecting the defence of apartheid on moral and theological grounds. It was a kairos moment for the DRMC. Prof. Gustav Bam advised the synod that the acceptance of the status confessionis necessarily should lead to the formulation of a confession. ${ }^{33}$

The synod appointed a committee, consisting of Rev. Isak Mentor, moderator of the DRMC, Rev. Dr. Allan Boesak, vice-moderator of the DRMC, and three lecturers from the University of the Western Cape (UWC) namely, Dr. Dirkie Smit, Prof. Jaap Durand and Prof. Gustav Bam, to draw up a draft confession of faith, known today as the Belhar Confession. Dirkie Smit, Jaap Durand and Gustav Bam had been

31 Agenda en Handelinge NGSK 1982, 439.

32 Acta Nederduitse Gereformeerde Kerk in Afrika 1983, 116-121; 360-361. (Acts of the Dutch Reformed Church in Africa 1983).

33 Agenda en Handelinge NGKA 1983, 22. 
lecturing at UWC, at the time a racially segregated tertiary institution. ${ }^{34}$ The drafters of the Belhar Confession were all people who were held in high regard in the DRMC. The Rev. Isak (Sakkie) Mentor was known in the DRMC circles as a conservative theologian. So I presume that some of the delegates were glad that he had been included in the commission. On the other side was the young Boesak, known to the delegates by his outspokenness on the apartheid situation and crosscutting issues related to social justice. Boesak had done extensive research in the Netherlands and America on the issue of being black and Reformed. Boesak, the newly elected president of the WARC, was known foremost in the DRMC for his dissertation, Farewell to innocence, where he stated that apartheid (separate development) was not only a political policy, but also a pseudo-religious ideology. On the other side, three distinguished theologians were included in the commission, namely Professors Jaap Durand, Gustav Bam, and Dr. Dirkie Smit. The latter only commenced his duties as senior lecturer of the DRMC in systematic theology at the faculty of theology at the UWC in February 1981. Furthermore, Dirkie Smit had not been in the synod when the decision was taken about him being nominated on the commission to draft a confession.

The commission entrusted the young Dirkie Smit to draft a document, because most of them were engaged in commission work during the synod. Ever since the article, "Die belydenis van dominee Dirkie" by Murray la Vita had been published in Die Burger on 26 May 2011, it became public knowledge that Dirkie Smit played a pivotal role in the drafting of the Belhar Confession. It is also a known fact that the authors of the Belhar Confession do not want to claim any personal honour for the drafting of the Confession. Kritzinger highlighted the role which the theological declaration of the Belydende Kring (BK) in August 1979 played as one of the significant documents used by the authors while formulating the Belhar Confession. ${ }^{35}$ The "Broederkring van NG Kerke" (BK) was established in 1974 in Bloemfontein by about 60 ministers and evangelists from the NG Kerk in Afrika (NGKA) and the NG Sendingkerk (NGSK). It was later called the Belydende Kring (BK). According to Kritzinger, it does not matter who wrote the Confession. I concur with Kritzinger in that confessions are formally approved in the Reformed tradition by a specific church, on the basis of

34 The University Education Act, Act No. 45 of 1959 made provision for the establishment of separate tertiary institutions for blacks, Indians, coloureds and whites, of which the UWC was one. Black people were not allowed to attend white universities without special permission by the government, and vice versa.

35 Kritzinger, K. 2010. Celebrating communal authorship: The Theological Declaration of the Belydende Kring (1979) and the Belhar Confession. In honour of Simon Maimela and in memory of Chris Loff. Studia Historiae Ecclesiasticae 36, (July 2010), 209-231. 
a well-established procedure involving local (church council), regional (presbytery) and national (synod) bodies. Once a confession has been formally approved by a Reformed church, that church "speaks" or "confesses" that particular confession, not the individual authors who formulated it or the committee which proposed it to the church. Communal authorship and ownership is therefore operative in the Belhar Confession. One should always remember that any text, once written, has little to do with the author. The delegates at the DRMC and DRCA synods were painfully aware of the hardships of apartheid and can rightfully be seen as co-authors of the Belhar Confession. The Confession only put into words their observation about the situation in South Africa. The Belhar Confession can therefore rather be seen as a communal endeavour.

The Belhar Confession is indeed the culmination of a variety of factors, processes and efforts in the DRMC, DRCA, BK and Alliance of Black Reformed Christians in Southern Africa (ABRESCA). The movement and philosophy of the BK found extension in the formation of the ABRECSA in 1981. ABRECSA was a broad Reformed forum constituted by members of the black DRC, Presbyterians and the Congregational Church. ABRECSA reflected on Reformed faith and its implications for opposing apartheid within and outside the church. The members of ABRESCA also influenced the decisions of the DRMC and the DRCA on social justice issues during the 1980s. According to Kritzinger, the first and clearest influence of the BK Declaration on the Belhar Confession is the one found in article 4 of the Belhar Confession. For example: "As God's property the church must be busy standing where God stands, viz. against injustice and with those who are denied justice" (BK Declaration), versus "We believe: that the church, belonging to God, should stand where God stands, namely against injustice and with the wronged" (Belhar Confession, Article 4). Chris Loff, as coordinator of the drafting team of the $\mathrm{BK}$, presented the draft declaration to the plenary of the $1979 \mathrm{BK}$ conference in Hammanskraal, for approval. Dr. Allan Boesak, one of the co-drafters of the Belhar Confession, was the chairperson of the BK at the time. The formulation by Chris Loff was approved at the BK's meeting. Kritzinger maintains that although the influence of the BK Declaration on the Belhar Confession is in most cases not verbatim, there are indeed discernible influences to be seen in the Belhar Confession.

\section{THE AUDIENCE OF THE BELHAR CONFESSION}

The next questions are: Was the Belhar Confession meant to be public or private? For whom was it written? What is known about the audience? The intended audience in the first instance were the DRMC congregants. With only a few small formal changes to the original formulation, the Confession and the accompanying letter 
were officially adopted by the 1982 DRMC synod. The draft of the Belhar Confession was published in 1982 and distributed in a booklet to all the congregations of the DRMC, in order for the church councils of the DRMC to comment. A long judicial process of discernment by the local congregations of the DRMC, which took four years, followed in the church. The members of the DRMC were aware that they contributed in one way or another also to the situation, and together they accepted responsibility for that which they confess.

On 12 June 1986, three months before the DRMC synod where the Belhar Confession would be approved, the government extended the state of emergency to cover the whole country. The State of Emergency Act empowered the government to declare an organisation unlawful and to control the distribution of publications. Meetings of more than twenty persons were declared unlawful, unless authorised by the magistrate. Even some of the presbyteries of the DRMC and DRCA could not meet, due to the unrest in South Africa. ${ }^{36}$ The apartheid government had the right to declare areas of "unrest" and to allow extraordinary measures to suppress protests in these areas. The state of emergency continued until 1990, when it was finally lifted by State President F. W. de Klerk. The General Law Amendment Act No. 37 of 1963, Section 17, authorised any commissioned officer to detain - without a warrant - any person suspected of a political crime and to hold them for 90 days without access to a lawyer. The Act also allowed for further declaration of unlawful organisations. The State President could declare any organisation or group of persons which had come into existence since 7 April 1960 to be unlawful. The delegates knew that under a state of emergency the Minister of Law and Order, the Commissioner of the South African Police or a magistrate or a commissioned officer could detain without trial any person for reasons of public safety. For example, the Reverends P. Moatse and K. E. Leputu were detained the same evening after a debate on apartheid in the regional synod of Northern Transvaal in 1986. Notwithstanding, the delegates at the 1986 DRMC synod approved the Belhar Confession. The acceptance of the Belhar Confession as an authority of faith in September 1986 can therefore be seen as an act of defiance. Boesak rightly stated that the Belhar Confession became the bedrock of theological reference and reflection, as well as a salient point of theological identity within the Uniting Reformed Church in Southern Africa. ${ }^{37}$

Solemnly, on Friday 26 September 1986 in Belhar, 400 of the 470 delegates of the DRMC rose to express their endorsement of the Belhar Confession, and thereby

36 Submission of the URCSA to the TRC 1997, 2.

37 Boesak, A. A. 2008. To stand where God stands: Reflections on the Confession of Belhar after 25 years. Studia Historiae Ecclesiasticae 34, (No. 1, July), 143-172. 
adopted the Belhar Confession as the fourth confession of the DRMC. ${ }^{38}$ Altogether 71 delegates voted against the adoption of the Belhar Confession, including Rev. Isak Mentor, ironically one of the co-drafters of the Belhar Confession. Mentor's proposal at the synod that the Belhar Confession should not be accepted, but should rather be referred, for the greatest possible unity, to all other Dutch Reformed churches in order to reach consensus with the other Reformed churches, was rejected with an overwhelming majority. The acceptance of the Belhar Confession held profound judicial implications for all clergy of the DRMC. Eventually it was expected of all ministers to sign the Belhar Confession. The synod, however, decided to accompany with pastoral sensitivity those who were not ready to accept the Belhar Confession. The writing as well as the ultimate adoption of the Belhar Confession was a risky business. For example, many clergy feared that their financial subsidies by the DRC could be revoked or declined.

Secondly, the DRMC also offered the Belhar Confession as a gift to the world. The 1986 DRMC synod requested the REC to include the Belhar Confession in the list of Reformed confessions in Article II of the REC constitution, to which all member churches have to subscribe. The REC's Harare assembly appealed to the member churches to consider accepting the Belhar Confession, and to report their decisions to the 1992 assembly. The REC member churches were requested to reflect upon the following: The history of the Belhar Confession; the purpose of the Belhar Confession; the question whether the Belhar Confession can stand alongside the classical confessions; the question whether the Belhar Confession is specifically South African in orientation, and whether that would be a hindrance; the question whether the Belhar Confession should be approved. The REC constituted a theological forum in order to promote discussion of the Belhar Confession, so that an enlightened decision could be made at the REC assembly in Athens. ${ }^{39}$ Consequently, by 1990, the Christian Reformed Church of North America (CRCNA) took official action on the request of the REC interim committee. The 1990 CRCNA synod declared that the Belhar Confession was in harmony with the Reformed faith as a body of truth as articulated in the historic Reformed confessions, and that it was in basic agreement with the REC and the CRCNA decisions on race made over the last decades, and therefore had no objection to its inclusion in the list of Reformed confessions in Article II of the REC Constitution. ${ }^{40}$

38 Agenda en Handelinge NGSK 1986, 718-747.

39 Schrotenboer, P.G. 1991. The Belhar Confession 1986. Theological Forum 19, (No. 2, July 1991), 1.

40 Christian Reformed Church of North America Acts 1990. Grand Rapids: CRCNA, 625. 
The 1987 DRCA synod referred the Belhar Confession to the Commission for Scripture and Confession in order to test the desirability of the acceptance of the Confession by the DRCA, and to determine to what extent the acceptance thereof by the DRCA may promote or delay the unification of the DRC family. The commission was tasked to table their findings during the recess to the federal council of the Reformed churches in South Africa, and to serve the next synod of the DRCA with proposals regarding the inclusion of the Belhar Confession in their confessional basis. On 1 October 1990, an extraordinary session of the general synod of the DRCA convened in Cape Town, with representatives from the six regional synods, i.e. Orange Free State, Phororo, Southern Transvaal, Northern Transvaal, Cape Province, and Natal. They approved the inclusion of the Belhar Confession in the confessional basis of the DRCA. ${ }^{41}$

Following the WARC decision in 1982, the Reformed Church in Africa (RCA) rejected the theological justification of apartheid as unscriptural and any attempt to practically support it as unchristian. The synod refrained from labelling apartheid as heresy. The 1990 RCA synod declared that it could identify with the content of the Belhar Confession, but could not accept it as a confession on the same level as the standards of unity, due to the fact that the social issues to which the Belhar Confession was referring are continuously subjected to change. The Belhar Confession was more doctrinal in nature, according to the RCA. ${ }^{42}$

At the 1990 DRC synod, the revised edition of Church and Society was adopted, with its call for confessing the DRC's role in establishing and practising apartheid. The synod decided to work towards the ideal of structural unity with the DRCA, DRMC and the RCA. On the matters of the status confessionis and the Belhar Confession, the DRC synod recognised the right of the DRMC to adopt the Belhar Confession, and concurred that the issues involved were of extreme importance to the DRMC. ${ }^{43}$ On the one hand, the synod regarded the Belhar Confession not to be in conflict with the contents of the Belgic Confession, the Heidelberg Catechism or the Canons of Dort, but on the other hand, the synod ascertained that Church and Society (Kerk en Samelewing) contained the DRC answer to the paragraphs containing "rejections" in the Belhar Confession. Furthermore, the synod pointed out that after the DRC's adoption of the revised Church and Society, some of the accusations levelled against

41 Agenda en Handelinge NGKA 1987, 413-414; Agenda en Handelinge NGKA 1990, 28 30, 49-50, 142-149, 205-298.

42 Agenda RCA 1990, 3; Agenda RCA 1990, 40-41; Acts RCA 1986, 31.

43 Meiring, The Confession of Belhar, 18-23. 
the DRC in the Belhar Confession were no longer applicable. ${ }^{44}$ The 1990 DRC synod was of the opinion that some phrases in the Belhar Confession, such as parts of Article 4, could have been formulated differently. The DRC synod preferred the wording of Church and Society concerning the affirmation of the Lord being the God of the poor and the wronged. The synod also emphasised that in future deliberations between the two churches, both documents, the Belhar Confession and Church and Society, should be used as a basis for discussions.

\section{ANALYSING THE BELHAR CONFESSION (INTERNAL ANALYSIS)}

\section{Main body of the document}

The questions are: What were the authors trying to communicate to its audience? What are the objectives of the Belhar Confession? What is the argument/thesis in the Belhar Confession? The Belhar Confession is a treatise. The structure of the text informs the reader about the thesis and objectives. The structure of the Belhar Confession is based on defining and presenting a problem/solution on three issues, namely, unity, justice, and reconciliation. The Belhar Confession identifies unity, reconciliation and justice as problems in apartheid South Africa and tries to provide a solution for the problem, mainly by trying to persuade the reader in affirmation and rejections. The Belhar Confession tries to convince, persuade and to motivate the reader to reject apartheid and to affirm fundamental biblical truths. The Belhar Confession, however, does not straightforwardly present information and arguments with regard to apartheid, discrimination, racism, et cetera. It rather employs rhetorical devices, namely affirmation and rejections. The Belhar Confession confesses its belief in justice as opposed to the practice of apartheid. The Belhar Confession is a call to action in order to change ideas, beliefs and behaviours on unity, justice and reconciliation. The handwritten text of the Belhar Confession is consistent with the official version of the Belhar Confession as well as the version in the draft Belhar Confession which had been issued to the DRMC congregations. According to Foucault, ${ }^{45}$ texts should subsequently be read as follows: What stands

44 Agenda van die Algemene Sinode van die Ned. Geref. Kerk te Kaapstad, 1986 (Agenda of the general synod of the Dutch Reformed Church in Cape Town 1986); Agenda en Acta van die Algemene Sinode van die Ned. Geref. Kerk te Bloemfontein, 1990 (Agenda and proceedings of the general synod of the Dutch Reformed Church in Bloemfontein 1990).

45 Foucault, M. 1973. The Birth of a Clinic: An archaeology of medical perception. Translated by A. M. Sheridan Smith. London: Tavistock, 50. 
there and what does not stand there. In combination, this way of reading text provides a coherent structure. The very same applies to the Belhar Confession. In an important article, Christina Landman asks whether justice should be embodied in the Belhar Confession in sexist language. It seems as though the drafters and early recipients of the Belhar Confession were unaware of these biases or assumptions. ${ }^{46}$

The argument and strategy utilised by the commission was to use biblical notions and words familiar to the members of the DRMC in order to achieve the goal of clearly stating that the DRCMC is against the theological justification of apartheid. It seems as though the draft was first completed and thereafter the biblical references were inserted before it had been tabled to the synod of the Dutch Reformed Mission Church (DRMC). With these biblical references, the drafters of the Confession give support to their thesis on reconciliation, justice and unity.

The Belhar Confession consists of five articles and an accompanying letter. The Confession begins with God and also closes (in article 5) with laudation to God. Article 2 deals with the church and her role in the world as well as the unity of the church. Article 3 deals with reconciliation in church and society, and Article 4 concentrates on how to bring about peace and justice in the world.

From its beginning, the Belhar Confession was supported by an accompanying letter. This letter is an important indicator for understanding the Confession itself. The accompanying letter consists only of four paragraphs. At the beginning of each paragraph is a short explanation before the letter itself follows. The first paragraph emphasises the seriousness of the situation in which the Gospel came into play, and asks for a radical decision of faith in the form of the Confession. The second paragraph emphasises that the authority of the Confession - as any Reformed confession - is derived from the Bible as the Word of God. The third paragraph indicates that the Confession is not aimed at specific people, or groups of people, or a church or churches, but against a false doctrine that can emerge in the church in the present and in the future. The fourth paragraph points to the implications of the Confession, namely, reconciliation and justice, as well as the dismantling of unjust church and social structures. The letter ends with a prayer and the firm conviction that the Lord will bring true peace by his Spirit. ${ }^{47}$ On the draft hand-written copy, the commission noted possible points which could be part of the envisaged point 4

46 Landman, C. 2003. Can justice be embodied in sexist language? A challenge to the Confession of Belhar. Ned. Geref. Teologiese Tydskrif47, (Nos. 1 \& 2, March/June), 283 291.

47 Belydenis van Belhar, Belhar Confession, IsiVumo SaseBelhar: Text and Commentary. 2006. Bellville: Konvent vir Eenheid Kaapland. 
of the said letter, namely the relationship of the Confession with other confessions, the obligation or freedom to underwrite the Confession as well as the call to all to associate them and to embody the Confession. The commission, however, never wrote down a fully-fledged article on this issue. Today this seems to be one of the major critiques against the Belhar Confession. ${ }^{48}$

\section{EVALUATING THE EVIDENCE (CONCLUSION)}

The Belhar Confession is a product of a communal society which was composed during the height of resistance against apartheid in South Africa. The Belhar Confession is first and foremost specifically South African in origin and is aimed at the country's historical context. Thus, the meaning of the Belhar Confession is bound up with its function within the community which produced it, and thesocial context. Taken out of its original context, the original meaning of a passage in the Belhar Confession can easily be lost.

Secondly, the Belhar Confession represents "a Christian view on racism ... and suffering from the perspective of those who suffered the realities of such inhumane conditions." ${ }^{39}$ Consequently, the above-mentioned historical evidence showcases that the Belhar Confession can be used as a discursive instrument in the reconciliation processes between different racial groups, minority groups, locally and abroad. The issues of racial inequality, discrimination, oppression, poverty and injustice which are being addressed by the Belhar Confession are timeless and universal themes. Thus, reading the Belhar Confession as a historical document allows us to interpret the past by providing the tools and evidence needed to make informed statements about the world around us, identify stated and unstated aspects, assumptions, presuppositions and possible motives not stated in the text.

48 Cooper, J. 2011. Why the Belhar Should Not Be a Confession,” Banner, June 2011. Online at http://www.calvin.edu/library/database/crcpi/fulltext/banner/2011-0600-0037.pdf [Accessed 22 June 2011]; Cooper, J. 2010. Reformed Matters: Context and Confusion: What Does the Belhar Confess?” Calvin Theological Seminary Forum, Fall 2010, 10-12. Online at https://internal.calvinseminary.edu/pubs/forum/10fall.pd/\#page=10 [Accessed 23 March 2012].

49 Botman, H. R. 2008. The Confession of Belhar and our common future. Perspectives, (May). Online at http://www.rca.org/page.aspx?pid=4048. [Accessed 23 March 2012]. 


\section{BIBLIOGRAPHY}

Acta van die Nederduitse Gereformeerde Kerk (Acts of the Dutch Reformed Church) 1829. Acta van die Nederduitse Gereformeerde Kerk (Acts of the Dutch Reformed Church) 1857.

Agenda van die Algemene Sinode van die Ned. Geref. Kerk te Kaapstad, 1986 Agenda en Acta van die Algemene Sinode van die Ned. Geref. Kerk te Bloemfontein, 1990.

Acta van die Nederduitse Gereformeerde Kerk in Afrika 1971.

Acta van die Nederduitse Gereformeerde Kerk in Afrika 1983.

Acts Reformed Church in Africa 1986.

Agenda en Handelinge NGSK 1978.

Agenda en Handelinge NGSK 1982.

Agenda en Handelinge NGSK 1986.

Agenda en Handelinge NGKA 1983.

Agenda en Handelinge NGKA 1987.

Agenda en Handelinge NGKA 1990.

Agenda Reformed Church in Africa 1990.

Adler, E. 1974. A small beginning. An assessment of the first five years of the Programme to Combat Racism. Geneva: WCC;

Adonis, J. A. 1982. Die afgebreekte skeidsmuur weer opgebou. Amsterdam: Rodopi, 78.

Agenda en Handelinge NGSK 1982 (Agenda and Proceedings DRMC 1982), 21.

Apartheid Legislation in South Africa. Online at http://www.sahistory.org.za/politicsand-society/apartheid-legislation-1850s-1970s [Accessed 11 March 2011]. 
Belydenis van Belhar, Belhar Confession, IsiVumo SaseBelhar: Text and Commentary. 2006. Bellville: Konvent vir Eenheid Kaapland.

Boesak, A. A. 2008. To stand where God stands: Reflections on the Confession of Belhar after 25 years. Studia Historiae Ecclesiasticae 34, (No. 1, July), 143-172.

Boesak, A. A. 1984. Black and Reformed. Bellville: Skotaville Publisers, 117

Botha, J. 1991. Belhar: Yes or no? Theological Forum 19, (No. 2, July), 2-10.

Botman, H. R. 2008. The Confession of Belhar and our common future. Perspectives, (May). Online at http://www.rca.org/page.aspx?pid=4048. [Accessed 23 March 2012].

Christian Reformed Church of North America Acts 1990. Grand Rapids: CRCNA, 625.

Cloete, G. D. \& Smit, D. J. 1984. A Moment of Truth: The Confession of the Dutch Reformed Mission Church. Grand Rapids: Eerdmans.

Coertzen, P. 2010. Ontstaanskenmerke van die Stellenbosche Teologiese Seminarium. NGTT, Deel 51 Supplement Teologie 150 + en CALVYN 500. 4155.

Cooper, J. 2011. Why the Belhar Should Not Be a Confession," Banner, June 2011. Online at http://www.calvin.edu/library/database/crcpi/fulltext/banner/2011-0600-0037. pdf [Accessed 22 June 2011].

Cooper, J. 2010. Reformed Matters: Context and Confusion: What Does the Belhar Confess?" Calvin Theological Seminary Forum, Fall 2010, 10-12. Online at https://internal.calvinseminary.edu/pubs/forum/10fall.pdf\#page=10 [Accessed 23 March 2012].

Die Naturellevraagstuk: referate gelewer op die Kerklike Kongres van die Gefedereerde Ned. Geref. Kerke in Suid-Afrika, byeengeroep deur die Federale Sendingraad, Bloemfontein, 4-6 April 1950. Kerklike Kongres van die Gefedereerde Ned. Geref. Kerke in Suid-Afrika: Bloemfontein.

Foucault, M. 1973. The Birth of a Clinic: An archaeology of medical perception. Translated by A. M. Sheridan Smith. London: Tavistock, 50. 
Klooster, F. 1991. The Belhar Confession 1986. Theological Forum 19, (No.1, March), 14-17.

Kriel, C. J. 1963. Die geskiedenis van die Ned. Gereformeerde Sendingkerk in Suid-Afrika 1881-1956. 'n Historiese studie van die sendingwerk onder die Kleurlingbevolking van Kaapland. Paarl: Paarldrukpers, 54.

Kritzinger, K. 2010. Celebrating communal authorship: The Theological Declaration of the Belydende Kring (1979) and the Belhar Confession. In honour of Simon Maimela and in memory of Chris Loff. Studia Historiae Ecclesiasticae 36, (July 2010), 209-231.

Landman, C. 2003. Can justice be embodied in sexist language? A challenge to the Confession of Belhar. Ned. Geref. Teologiese Tydskrif 47, (Nos. 1 \& 2, March/ June), 283-291.

Loff, C. J. A. 1981. Dogter of verstoteling? Kantaantekeninge by die geskiedenis van die Ned. Geref. Sendingkerk in Suid-Afrika. Cape Town: Maranatha, 18-19.

McGarrahan, E. T. 2010. A Study of the Belhar Confession and its Accompanying Letter. Office of Theology and Worship, General Assembly Council Presbyterian Church (USA). Online at https://www.pc-biz.org/Explorer. aspx?id=3353\&promolD=17 [Accessed 22 March 2011].

Meiring, P. 1991. The Belhar Confession 1986: A Dutch Reformed perspective. Theological Forum 19, (No. 1, March 1991), 18-23.

Schrotenboer, P.G. 1991. The Belhar Confession 1986. Theological Forum 19, (No. 2, July 1991), 1.

Submission of the URCSA to the TRC 1997. URCSA: Bloemfontein, 1-5.Van Houten, R. L. 1997. Introduction. Theological Forum 25, (No. 4, December 1997); CRCNA Acts 1990 Online at http://www.crcna.org/pages/belhar.cfm [Accessed 22 March 2011].

WARC Seoul 1990. 1989 Proceedings of the 22nd General Council, ed. Edmond Perret, Geneva: WARC, 173-175, 279-281; Ottawa 1982. Proceedings of the $21^{\text {st }}$ General Council of the World Alliance of Reformed Churches, 177f., Ottawa, Canada, August 17-27, 1982. Geneva, Offices of the WARC, 1983. 


\section{KEY WORDS}

Apartheid

Belhar Confession

Belydende Kring (BK)

Holy Communion

Status confessionis

\section{CONTACT DETAILS}

Dr Mary-Anne Plaatjies-van Huffel,

Fakulteit Teologie

Universiteit van Stellenbosch

Privaatsak X1

7602 MATIELAND

mapvanhuffel@sun.ac.za 